\title{
THE DESCENT OF THE ESCHATOLOGICAL TEMPLE IN THE FORM OF THE SPIRIT AT PENTECOST:

\author{
PART 1: THE CLEAREST EVIDENCE ${ }^{1}$
}

\author{
G. K. Beale
}

\begin{abstract}
Summary
This article argues that certain Old Testament and early Jewish references to a temple (usually a heavenly or sometimes a latter-day temple) have been formative for the depiction of the Spirit appearing as fire and for other associated features in Acts 2. The conclusion drawn from this is that the coming of the Spirit at Pentecost is a description of the inaugurated eschatological descent to earth of the heavenly temple to establish God's end-time people as a part of this temple.
\end{abstract}

\section{Introduction}

While the Gospels narrate to some extent Jesus' establishment of himself as the end-time temple (e.g. John 2:19-22), and while the New Testament elsewhere refers to the Church as the latter-day 'temple' or 'temple of the Holy Spirit' (e.g. 2 Cor. 6:16), there is no explicit mention of the decisive time when the Church was first founded as the eschatological temple. Furthermore, the Gospel of Luke (and Matthew) narrates a keen interest in Israel's earthly temple, both with respect to

1 This first of two articles is an attempt to substantiate in much more depth an argument, apparently never previously proposed (but set forth in my recent book, The Temple and the Church's Mission [Leicester: InterVarsity, 2004]: 201-15), whose thesis is well-expressed in the title of this article. The second installment will offer further new evidence in favor of this thesis. I am thankful for constructive comments in response to the oral form of this article which was delivered as the Biblical Theology Lecture at the annual Tyndale Fellowship Conference in July 2004. Thanks go especially to Desmond Alexander, as well as to Chris Beetham, Ben Gladd and David Lincicum. 
its proper and improper use, ${ }^{2}$ and then predicts its destruction. In contrast to Matthew, Mark, and John, who mention the replacement of Israel's temple by Christ's rebuilding of a new temple through his resurrection (Matt. 26:61; Mark 14:58; 15:29; John 2:19-22), Luke never tells the reader who or what will replace the temple. The purpose of this paper is to explore the possibility that it is in Acts 2 that Luke narrates the initial establishment of the church as the latter-day temple in replacement or, better, in escalated continuation of the true temple of God. In particular, we will argue that God's heavenly tabernacling and theophanic presence began to descend on his people at Pentecost in the form of the Spirit, thus extending the heavenly temple down to earth to include his people in it by building them into it. This will be shown through analyzing various Old Testament and Jewish allusions and backgrounds, which in their original contexts are integrally connected with the temple. Some of these allusions and backgrounds have more validity than others, but the hope is to adduce a cumulative argument that carries a sufficient degree of persuasiveness to undergird the proposal. Though the words 'temple' or 'sanctuary' or synonyms are not used in Acts 2, the contention of this paper is that the concept of the descending heavenly temple is woven throughout and forms part of the underlying meaning of the narrative.

A number of commentators have understood that the fiery coming of the Spirit is a theophany, but no one, as far as I am aware, has suggested that an eschatological temple is in mind in Acts 2. I am proposing that Acts 2 depicts not a mere theophany but a theophany in a newly inaugurated eschatological temple, whereby the heavenly temple is being extended to earth in a greater way than it had been to the holy of holies in Israel's temple. It is true, of course, that the theophanic presence could be perceived in the Old Testament as operating apparently not in connection to the heavenly or earthly temple. Nevertheless, often the Old Testament depicts theophanies either in the heavenly or earthly temple, and this was the place where the divine presence was considered as always being located, until the destruction of the Solomonic temple. Indeed, the theophanic presence was the essence and center of Israel's tabernacle and temple.

2 In this respect, Luke and Matthew refer to the temple often (e.g. 22x iعpòv, vaòs, and oíkós are so used, while Mark makes 15 such references, and Acts makes 25, though the latter never applies vaò to Israel's temple). 
Thus, the proposal that Acts 2 is not a mere theophany but one in the context of a new temple is in keeping with the typical templetheophanies of the Old Testament, though at Pentecost this begins to happen on an escalated eschatological level. The fact that several Old Testament texts prophesy that the end-time theophanic presence will be revealed to God's people in a new expanded non-architectural temple enhances our view that this is just what Acts 2 portrays as beginning (see Isa. 4:2-6; 30: 27-30; Jer. 3:16-17; Zech. 1:16-2:13; cf. Ezek. 4046 and Sib. Or. 5:414-432).

\section{A Relationship Between the Tongues of Babel and Pentecost?}

Though there is much debate, many believe that tongues at Pentecost are best seen, at least to some degree, against the background of the tower of Babel. Babel's sin of uniting and consequent judgement of confused languages and of people being scattered throughout the earth is reversed at Pentecost: God causes representatives from the same scattered nations to unite in Jerusalem in order that they might receive the blessing of understanding different languages, as if all these languages were one, since the result was that all heard the same message.

Ancient Near Eastern scholarship has shown that the judgement at Babel occurred as a result of the people uniting to build a temple-tower in order to force God to come down from heaven in blessing. Such cultic towers were typical of the time in ancient Mesopotamia. Their purpose was to serve as a gateway between heaven and earth whereby the god could come down and even refresh himself on the way down to the earthly temple.

Though many doubt any trace of a Babel background in Acts 2, we think the cumulative evidence points to its presence to some extent. The limits of this article do not allow a fuller presentation of this cumulative evidence. Nevertheless, we do want to note that the significance of the temple background of Babel for Acts 2 has apparently not been previously considered. In this regard, all we wish to indicate by this introductory section on Babel is that part of its cultic import may be to set in contrast the new temple that emerges along with the phenomenon of tongues, which now has been transformed into 
blessing. It is to the evidence in Acts 2 for such a new temple that we now turn our attention. ${ }^{3}$

\section{Tongues of Pentecost as a Theophany of a Latter-Day Sinai Sanctuary}

First, we will make an attempt to establish the Sinai background (which, to a significant extent, is a summary of the work of others), and then we will endeavor to show how it relates to the notion of the new temple.

The appearance of 'tongues as of fire' is an expression of the coming Spirit that reflects a theophany. But we may say more: it appears to be a theophany associated with the descending divine presence of the heavenly temple. A number of considerations point to this.

First, the mention that 'there came from heaven a noise like a violent, rushing wind' and that there appeared 'tongues as of fire' calls to mind the typical theophanies of the Old Testament. God appeared in these theophanies with a thunderous noise and in the form of fire. The first great theophany of the Old Testament was at Sinai, where 'God descended on it in fire' and appeared in the midst of loud 'voices and torches and a thick cloud' and 'fire' (e.g. Exod. 19:16-20; 20:18; Pseudo-Philo, Bib. Ant. 11:5 adds that at Sinai 'winds ... roared,' and Philo, Decalogue 44, says that there was a 'rush of heaven-sent fire,' which is comparable to the Acts 2:2 imagery of 'a noise like a violent, rushing, wind;' ${ }^{4}$ Josephus, Ant. 3:80 says there were 'blustering winds ... lightning'). Sinai was the model theophany for most later similar divine appearances in the Old Testament, and to some degree God's

3 See Beale, Temple and Church's Mission, 201-3, for an expansion of this section on the Babel background.

4 Ezekiel 1 portrays a theophany patterned after Sinai (so Niehaus, God at Sinai, [Grand Rapids: Zondervan, 1995]: 254-62), which is introduced like that at Pentecost: 'the heavens were opened ... a sweeping wind came' $(1: 1,4$; cf. Acts $2: 2$ : 'suddenly there came from heaven a noise like a violent, rushing wind'); the wind in Ezekiel 1 comes with a 'cloud' that has fire in its midst (1:4) and therein four angelic creatures described as having in their midst 'something that looked like burning coals of fire, like torches darting back and forth ... The fire was bright, and lightning was flashing from the fire' $(1: 13)$; and coming from the midst of the fire 'the voice of the Mighty One, the voice [or sound] of speech' (1:24 of LXX Alexandrinus). 
coming at Sinai stands in the background of the Spirit's coming at Pentecost. ${ }^{5}$

The portrayal of the Sinai theophany includes reference to 'all the people' who 'saw the voices [sounds] and the torches [or lamps: LXX has $\lambda \alpha \mu \pi \alpha \dot{s}]$, and the voice of the trumpet' (which is a straightforward rendering of Exod. 20:18 of MT [LXX has singular 'voice']; see likewise Deut. 4:12, 36; 5:22). Deut. 33:2 refers to God who 'came from Sinai' and 'at his right hand there was a fiery law 6 for them,' which is equated with 'your words' which Israel 'received' (Deut. 33:3). The phrase $\dot{\omega} \sigma \varepsilon i$ îि in Acts $2: 3$ may have been partially influenced by Exodus 24:17: 'the image of the glory of the Lord was as

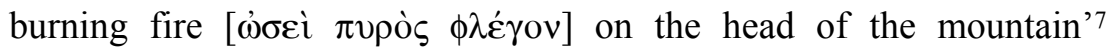
(similarly also 19:18).

Especially this aspect of the Sinai depiction and the way it was developed in early Judaism, is similar to that at Pentecost, where people saw 'tongues of fire being distributed' (Acts 2:3). ${ }^{8}$ In this regard, Philo's first century description of God's appearance at Sinai may not be a haphazard parallel: God's revelation came 'from the midst of the fire that streamed from heaven' as a 'voice' ( $\phi \omega v \eta$ ') being

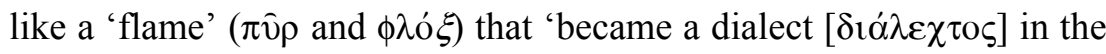
language familiar to the audience,' which caused 'amazement' (Decalogue 46, a parallel noted by several commentators; note the

5 So Niehaus, God at Sinai, passim, and in particular, 371; Niehaus' work traces the biblical-theological development of the Sinai theophany throughout the Old and New Testaments.

6 This is the reading of some mss. of the Samaritan Pentateuch (5th cent. BC), the Qumran copy of Deut. 33:2, the Vulgate, as well as 程 (a 16th cent. Heb. ms.). Other

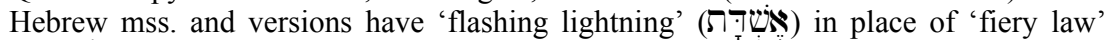
( $\left(\Omega_{T}\right)$, while the LXX has 'with his angels' in place of 'a fiery law for them' (or alternatively, in place of 'flashing lightning for them'). Regardless of the original reading, it is clear that 'fiery law' has ancient attestation, and certainly pre-dated the NT period, thus, at least, representing perhaps the earliest interpretation of the Deuteronomy text.

7 A suggestion made by G. Menzies, 'Pre-Lucan Occurrences of the Phrase

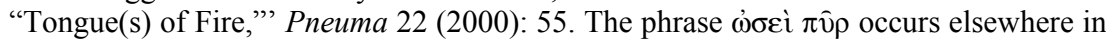
the LXX only at Job 28:5; Ps. 82:5; 117:12; cf. Dan. 7:9; 10:6.

8 E.g. see Mekilta de-Rab. Ishmael, Tract. Bahodesh 9, which interprets Exod. 20:8 ('and all the people saw the thunderings and the lightnings') by Ps. 29:7: 'the voice of the Lord hewed out flames of fire.' So also Sifre Deut., Piska 343 and Midr. Pss. 119:60 on Exod. 19:19. Midr. Tanhuma Yelammedenu reflecting on Exod. 19:18 says 'the entire Torah was of fire;' so also Sifre Deut., Piska 343 on Deut. 33:2 which cites Exod. 20:19 ('the words of Torah are likened to fire'); Mekilta, Bahodesh 4.3-4 also asserts that 'the Torah is fire, was given from the midst of fire, and is comparable to fire.' 
identical wording in Acts 2:3 and 2:6). In addition, Philo says elsewhere that God made an 'invisible sound' to have 'shape' and to become 'flaming fire [ $\pi \hat{v} \rho]$ ' that was 'sounded forth like the breath $[\pi v \varepsilon v \hat{\mu} \alpha]$ through a trumpet an articular voice [ $\phi \omega v \eta$ ] so loud that it appeared to be equally audible to the farthest as well as the nearest,' and the 'new miraculous voice was set in action and kept in flame

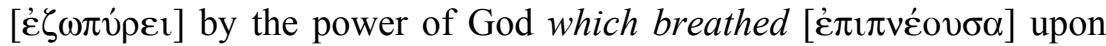
it' (Decalogue 35). Philo's rendering is not that far removed from the above-mentioned account in Exodus, where 'voices' is closely linked to 'torches' of fire: 'all the people saw the voices and the torches' (Exod. 20:18; LXX has 'all the people saw the voice and the torches,' which Philo cites in support). Elsewhere Philo describes God's 'voice' at Sinai (again citing LXX of Exod. 20:18) as 'light' and to be 'shining with intense brilliance' (Migration of Abraham 47). Even those

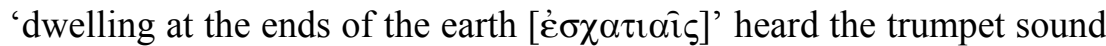
at Sinai which was designed to cause them to conclude 'that such

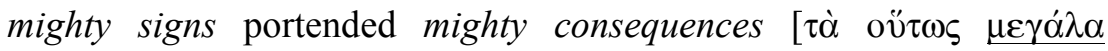

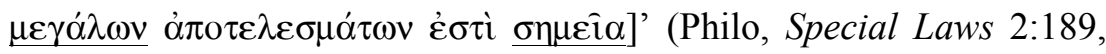
with which the virtually identical wording is to be compared in Acts $1: 8 ; 2: 11,19,22) .{ }^{9}$ Sectors of Judaism also spoke of God's revelation at Sinai as being 'in the holy tongue' (b. Sotah 42a on Exod. 19:19), being 'given in fire,' 10 and as being 'prophecy' (Midr. Tanhuma Gen. 8:23; Midr. Rab. Exod. 28:6; Targ. Ps. 68:34).

In fact, while one could think that Luke's account of Pentecost may contain no direct references from the Sinai theophany, ${ }^{11}$ the following survey shows various kinds of links and even more 'indirect allusions' than we have shown above to indicate that Luke was aware of the background of Sinai in his depiction of Pentecost. ${ }^{12}$

9 On which see Wedderburn, 'Redaction in Acts 2:1-13,' 36-37, and M. Turner, Power from on High (JPTSS 9; Sheffield: Academic Press, 1996): 283-84, who have drawn out the parallels between Philo's portrayal of Sinai and Acts 2 more than most who have observed its parallel significance.

10 E.g. Targ. Exod. Neof. 1 and Ps-Jon. 20:1-3. In this respect, God's flaming revelatory words at Sinai can be appealed to in order to explain why a 'flame [of fire] was burning round' a rabbi when he was 'expounding Scripture' (Midr. Rab. Lev. 16.4), i.e. the rabbi stands in the prophetic tradition that originated with Moses at Sinai; so identically Midr. Rab. Ruth 6.4 (=Midr. Rab. Eccles. 7.8,§1; Midr. Song of Songs 1.10,2; likewise y. Hagigah 2.1.

11 Though Acts 2:3 may be an exception.

12 So J. A. Fitzmyer, The Acts of the Apostles (AB 31; New York: Doubleday, 1998): 234. For the following first five major parallels, see J. Dupont, The Salvation of the Gentiles (New York: Paulist, 1967): 35-42. Some have attempted to propose a 
(1) The Essene and Pharisaic computation of the feast of Pentecost coincided with the date that some believe Exodus 19:1 gives for the time of the events on Sinai. The tradition in second century BC Judaism (Jubilees and DSS) reveals that the Festival of Weeks (Pentecost) was, not only a celebration of the fruits of the harvest, but also inextricably linked to the revelation at Sinai, particularly the establishing of the covenant between Israel and God (Pentecost was to occur 50 days after the celebration of Passover). In this respect, 'the Festival of Weeks was the date for making and remembering the biblical covenants and for renewing the Sinaitic covenant.' 13 Jubilees 6:17 (2nd cent. BC) says that Israel 'should observe the feast of Shebuot ... once per year, in order to renew the covenant in all (respects), year by year.' Pentecost as a festival of covenant renewal can plausibly be traced all the way back, at least, to 2 Chronicles 15:10-14. ${ }^{14}$ Later Jewish tradition made Exodus 19 the lectionary reading for the celebration of Pentecost (b. Meg. 31a). ${ }^{15}$

(2) There was a unanimity of spirit by people in the same sacred space (cf. Exod. 19:8; Targ. Ps-J. Exod. 19:2; Mekilta Exod. 19:2, 8; 20:2 with Acts 1:14; 2:1-2);

Hellenistic background to Pentecost: e.g. in the festival praise of Apollo by the Delian maidens, people of different dialects perceived that they were uttering the praise in their respective tongues (see H. J. Tschiedel, 'Ein Pfingstwunder im Apollonhymnas [Hymn. Hom. Ap. 156-64 and Apg. 2,1-13],' ZeitReGeist 27 [1975]: 22-39 [citing New Testament Abstracts $20\{1976\}: 4]$ ). See also the line in Virgil where 'a light tongue of flame' danced 'above the head of Julus,' which is interpreted as a promise of coming kingship and which is confirmed by a 'falling star' (cited by Niehaus, God of Sinai: 353, from H. R. Faircloth, Virgil, vol. 1 [London: Heinemann, 1925]: 341). See the wording of these and other relevant texts cited in P. W. van der Horst, 'Hellenistic Parallels to the Acts of the Apostles (2.1-47),' JSNT 25 (1985): 49-50, where he notes a series of texts where 'wind and especially fire (often on the head) are frequently regarded as signs of divine presence.' To whatever degree such backgrounds could be in mind, our overall argument in this essay is that the OT and derivative Jewish traditions form the dominant background.

13 J. C. VanderKam, 'The Festival of Weeks,' 204. See likewise, Turner, Power from on High: $280-82$, and R. Le Deut, 'Pentecost and Jewish Tradition,' Doctrine and Life 20 (1970): 250-67, for associations between the law-giving at Sinai and Pentecost in Judaism.

14 M. Weinfeld, 'Pentecost as Festival of the Giving of the Law,' Immanuel 8 (1978): 8-11, who also cites references to the same notion in Psalms 50 and 81; B. Berends, 'What Do We Celebrate at Pentecost?,' Vox reformata 63 (1998): 53-54.

15 See B. D. Chilton, 'Festivals and Holy Days: Jewish,' in Dictionary of New Testament Background, edited by C. A. Evans and S. E. Porter (Downers Grove: IVP, 2000): 374; on which, see also A. T. Lincoln, Ephesians (WBC; Dallas: Word, 1990): 243-44, who also points out that Exodus 19-20 and Numbers 17-18 were read during Pentecost in the synagogue liturgy. 
(3) in addition to the verbal parallels between the theophanic phenomena already cited, more still may be observed (cf. portrayal of

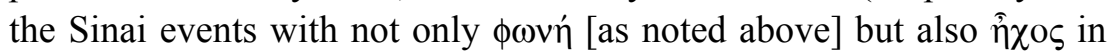
Philo [Decalogue 33] and Hebrews 12:18-19, and likewise see Acts 2:2, 6; $\phi \omega v \eta$ is used repeatedly in Exodus 19:16-20:18 and in 19:16 $\phi \omega v \eta$ occurs together with the verbal form of $\hat{\eta} \chi \circ \varsigma[\hat{\eta} \chi \dot{\varepsilon} \omega ;$ ms. 59 reads the noun form $\eta \chi 0 \hat{i}$; likewise note the use of $\gamma^{\prime} \mathbf{v}(\mu \alpha \imath+\phi \omega v \eta \dot{~ i n ~ E x o d . ~}$ 19:16, 19 and Acts 2:6);

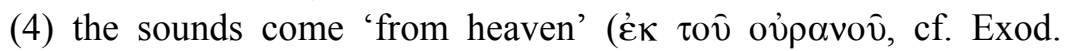
20:22; Deut. 4:36 and Acts 2:2);

(5) Jewish exegetical tradition on Exodus 19 held that the fiery voice or tongue was 'divided' in its application to people from all nations who heard it but rejected it and were judged, and often God's fire-like voice is said to be divided into 'seventy tongues' or 'languages'16 (cf. Jewish exegetical tradition on Exodus 19 with Acts 2:3). ${ }^{17}$ The Jewish tradition and the comparable phenomenon in Acts 2 both probably go back to some degree to earlier second temple interpretations of OT passages, especially Exodus 20:18a, pertaining to

\footnotetext{
16 Midr. Pss. 92:3 ('for the word divided itself ... into seventy languages ... as when a man strikes an anvil and causes the sparks to fly off into all directions ... He, let the word go out of his mouth, it divided itself into many radiances'); almost identically see b. Shabbath $88 \mathrm{~b}$ ('just as a hammer is divided into many sparks, so [like dividing sparks] every single word that went forth from the Holy One ... was divided into seventy languages'); virtually the same, note also the following, where also the divine voice and fire are directly associated: Midr. Tanhuma Exod. 1.22; Midr. Rab. Exod. 5.9; 28.6 (though the latter not mentioning 'fire'). Another Jewish tradition affirmed that Solomon set up ten lampstands (corresponding to the 'number of words revealed on Sinai') with seven lamps each, which equal 70 'to correspond to the seventy nations' (so Ginzberg, Legends, III, 161). Related to this tradition is that which viewed the nations as speaking a total of seventy languages (Tanna Debe Eliyahu Rabbah, ER, p. 34; Midr. Rab. Lev. 2.8; Midr. Rab. Num. 14:5). Perhaps the tradition that God had seventy names is related to this (i.e. it is appropriate that the God of the whole world [= 70 nations] would have seventy names): cf. 3 En. 48B; Targ. Songs 2:17 (on which see P. S. Alexander, The Targum of Canticles [Aramaic Bible 17A; Collegeville, MN: Liturgical Press, 2003]: 115, n. 114, for further references in later Judaism; cf. Midr. Rab. Num. 14.5, which relates the seventy languages to God's seventy letter or syllable name).

17 With respect generally to God addressing the Law to the nations of the world at Sinai, cf.: Midr. Rab. Num. 14.10; Sifre Deut. Piska 343; Mekilta de Rab. Ishmael, Bahodesh 5. For 'the sound of the trumpet' (Exod. 19:16) reaching 'the ends of the universe' and to those dwelling at the 'ends of the earth,' see Philo, Special Laws 2.189 (on which cf. Acts 1:8, where the witness through the Spirit to begin at Pentecost in Jerusalem is to extend 'unto the end of the earth'). More generally 'the study of Torah is likened to fire' ('Aboth D'Rab. Nathan, Minor Tract. Tal. 25a).
} 
the revelation of the Law at Sinai. ${ }^{18}$ The repeated comment that the Sinai revelation was divided into 'seventy languages' identifies it with the division of humanity's one language into seventy languages at Babel, perhaps implying that these Jewish commentators viewed Sinai as a continuing judgement on the nations. This has resemblance to the mention of 'tongues being divided' (Acts 2:3), echoing the traditional way of referring to the nations spreading out from Babel as the nations being 'divided.' 19

(6) Accordingly, the ascension of Jesus directly preceding the revelation at Pentecost parallels the ascent of Moses directly preceding the giving of the Law at Sinai. ${ }^{20}$ In particular:

(a) Jesus' post-resurrection ministry occurred over a period of forty days (Acts 1:3), which recalls Moses two stays on top of Mount Sinai.

(b) The ascension occurred on a mountain (Acts 1:11-12; cf. Luke 24:50), and a cloud concealed Jesus from the sight of his followers (Acts 1:9), echoing Moses entering the cloud at Mount Sinai as he was ascending there (Exod. 24:15-18; cf. also the cloud around Yahweh at Mount Sinai [Exod. 19:16]). The cloud at Sinai is also said to have 'descended' on the mountain (e.g. Exod. 19:11, 16-20). What is striking about this last observation is that elsewhere the Old Testament identifies God's 'Spirit' with the fiery 'cloud' that descended on Sinai (most explicitly, see Neh. 9:12-13 and cf. Neh. 9:19-20, as well as Num. 11:24-30, which is a development of the Sinai account in Exodus 24, on which see below at discussion of the use of Numb. 11 in Acts 2). ${ }^{21}$

(c) The last part of Acts 1 is about restoring the number of the apostles to twelve, just as the twelve tribes were present at the covenant (Exod. 24:1-8).

\footnotetext{
18 N. Neudecker, “"Das ganze Volk die Stimmen ... ": Haggadische Auslegung und Pfingstbericht,' Biblica 78 (1997): 329-49.

19 E.g. 3 En. $45: 3$ refers to this as the 'division of tongues.' So likewise Deut. 32:8; Pseudo-Philo, Bib. Antiq. 7:3, 5; Sib. Or. 3:105; 8:4-5; 11:10-16.

20 VanderKam, 'Festival of Weeks and Pentecost,' 196, 204, as well as passim, who adduces even more parallels with Sinai than these here, as well as acknowledging some differences, though he does not see them nullifying the overwhelming positive parallels.

21 In addition to these two texts, see also Isa. 4:4-6; 63:11-14; Hag. 2:4-6; Ps. 143:10, as well as W. N. Wilder, Echoes of the Exodus Narrative in the Context and Background of Galatians 5:18 (Studies in Biblical Literature 23; New York: Peter Lang, 2001): 121-74, who discusses in some detail the identification of the cloud with the Spirit in the last three texts together with Nehemiah 9 (though the latter is the clearest example).
} 
(d) Luke's use of Moses as a type of Jesus elsewhere indicates that the reference to the Sinai theophany in Acts 2 should not be surprising (cf. Acts 3:23-24; 7:20-41; cf. also Luke 24:27).22 Particularly striking is the matching description of Moses who 'received living oracles to give to us' (Acts 7:38) with that of Jesus who 'having received the Holy Spirit, poured forth this which you see and hear' $(2: 33) .{ }^{23}$

All of these parallels suggest that Luke was intending to some degree that his readers have in mind God's revelation to Moses at Sinai as a backdrop to understand the events leading up to and climaxing at Pentecost.

We have adduced several lines of evidence in favor of a SinaiPentecost identification. Some of the arguments in favor of this interpretation may not stand on their own, but they take on more persuasive strength when viewed in light of the other lines of evidence. Though some scholars have doubted any presence of a Sinai background, ${ }^{24}$ the overall weight of the cumulative arguments points to the probability of it. Indeed, as Wedderburn has concluded, 'it is hard to maintain that all these parallels are purely coincidental — that surely stretches credulity too far ...' ${ }^{25}$

The upshot of all these affinities with the Sinai revelation is to compare them with an observation not made so far: I have argued elsewhere that Exodus 19 and 24 portrays Sinai as a temple or 'tabernacle' in which God's revelatory presence dwelt, an identification made by several Old Testament commentators (for a summary of which see excursus below). If this conclusion is correct, then it contributes to the other evidence throughout this essay that the theophany at Pentecost also may be understood as the irrupting of a newly emerging temple. ${ }^{26}$ In support of this thesis is the hitherto

22 On which see further Johnson, Acts: 13, 46.

23 Following Johnson, Acts: 46.

24 On which see Turner, Power from on High: 279-80, 284-85, who is in agreement with our argument and cites others in favor, as well as those against it.

25 Wedderburn, 'Redaction in Acts $2: 1-13,38$, though he unpersuasively says that Luke was not aware of these parallels because he was merely and unreflectively using an earlier Christian-Pentecost tradition containing them, of which the formers of that tradition were aware. Others doubt that Pentecost was connected with the renewal of the covenant at Sinai, that the rabbinic parallels are irrelevant (since they are later), and that there is no direct evidence in Acts 2 of allusions to the giving of the Law at Sinai (e.g. Barrett, Acts, vol. 1: 111-12; Polhill, Acts: 104-5).

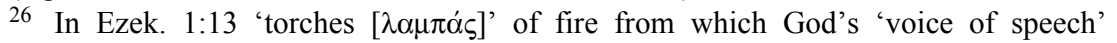
emanates (Ezek. 1:24) also is part of a heavenly temple scene partially allusive to the Sinai theophany, on which see n. 4 above. 
unobserved parallel in Philo (in commenting on Exod. 24:1b), where Moses is said 'to enter a dark cloud [on Sinai] and to dwell in the forecourt of the palace/temple ${ }^{27}$ of the Father,' where God's appearance is referred to as 'the tongues of flame' (this last phrase is the Loeb translator's paraphrastic rendering of the Armenian's more literal 'sparks of rays;' ${ }^{28}$ Quest. Exod. 2:28); a few sections later (Quest. Exod. 2:33), Philo interprets the sacrifices offered by Moses in Exodus $24: 6$ to be not only a 'sacred offering' but also a 'sacred unction $[\chi \rho i \sigma \mu \alpha] \ldots$ in order that (men [including Israel at Sinai]) may be

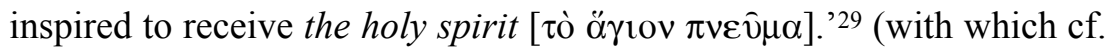
Acts 2:3, 38b respectively, 'there appeared to them tongues as of fire,' and 'you will receive the gift of the Holy Spirit'). The earliest (160 BC) and clearest example of Judaism's identification of Sinai as a sanctuary is Jubilees 8:19: 'And he [Noah] knew that the Garden of Eden was the holy of holies and the dwelling of the Lord. And Mount Sinai (was) in the midst of the desert and Mount Zion (was) in the midst of the navel of the earth. The three of these were created as holy places, one facing the other.'

27 R. Marcus, ed., Philo, Supplement II, Questions and Answers on Exodus (Loeb Classical Library; London: Heinemann, 1953): 69, has only 'palace;' for the rendering 'palace/temple' see P. Borgen, 'Moses, Jesus, and the Roman Emperor: Observations in Philo's Writings and the Revelation of John,' NovT 38 (1996): 151. Marcus also proposes that the Greek equivalent for the Armenian 'forecourt' is $\alpha \dot{\lambda} \lambda \dot{\eta}$, which occurs only 12 times in Philo, nine of which refer to the court of Israel's tabernacle or temple, and six of these referring to the court of the tabernacle that was shown to Moses on Sinai (Mos. 2.80, 82, 90, 91a, 91b, 93; see further P. Borgen, K. Fuglseth, and R. Skarsten, The Philo Index (Leiden: Brill, 2000): 55. In particular, in Preliminary Studies 116-17, Philo says that 'God's dwelling-place, the tabernacle,' is symbolic of

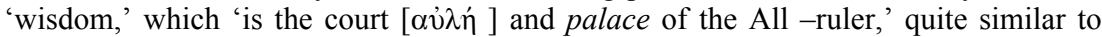
Quest. Exod. 2:28 and pointing further to the latter being a reference to God's heavenly temple-palace. Also of note is the observation that $\alpha \dot{v} \lambda \dot{\eta}$ occurs in the Pentateuch (LXX), Philo's frame of reference in Quest. Exod., exclusively with the meaning of a 'court' in the tabernacle $(35 \mathrm{x})$. Sometimes the word can refer only to a court in a king's palace (e.g. see uses in Esther and Jeremiah), but the majority of the references throughout the OT are the same as in the Pentateuch.

28 Marcus, Philo, Supplement II, Questions and Answers on Exodus: 69.

29 The bracketed Greek represents Marcus' (pp. 73-74) suggested Greek equivalents of the Armenian. 


\section{4. 'Tongues of Fire' and Comparable Depictions in the Old Testament as a Theophany from a Heavenly Sanctuary}

Sinai is the only background that portrays the image of speech in the midst of fire. The actual phrase 'tongues as of fire' occurs in two Old Testament passages. Isaiah 30:27-30 refers to God in the following manner: 'descending' apparently from his heavenly temple, which is located far away ('a remote place' and 'the mountain of the Lord'), appearing in 'dense ... smoke ... His tongue like a consuming fire

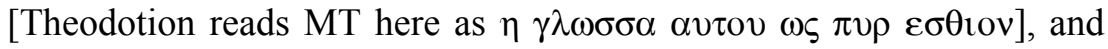
his breath [Spirit = רוּ] like an overflowing torrent ... in the flame of a consuming fire;' and 'the Lord will cause His voice of authority to be heard.' 'The name of the Lord' (30:27) elsewhere refers to God's presence located far away and 'high above all nations ... above the heavens; 'Mount Zion' (cf. 30:29) was understood to be 'in the far north' (Ps. 48:2), and God's throne was viewed to be far above in the heavens (Ps. 113:4-6]; cf. Isa. 14:13). Also God's presence in his heavenly temple is viewed to be in a very high place and thus geographically separated and far from the earth (Deut. 26:15; Ps. 18:613; 102:19; Isa. 57:15-16 [LXX]; 63:15 and 64:1; Jer. 25:30; Micah 1:2-3; implicitly cf. Pss. 80:1, 14; 92:8; 97:9; 113:4-6; 123:1).

Isaiah 30:27-30 itself clearly alludes to the prototypical Sinai theophany. ${ }^{30}$ The theophany is directly associated with 'the mountain of the Lord' (30:29c), from or to where his fiery, storm-like presence appears to descend (30:30). This is significant since the same expression 'the mountain of the Lord' elsewhere in Isaiah refers to God's eschatological temple (Isa. 2:3: 'Come, let us go up to the mountain of the Lord, to the house of the God of Jacob;' cf. also 2:2, 'the mountain of the house of the Lord;' see similarly 11:9; 27:13; $56: 7 ; 57: 7,13 ; 65: 11)$. Often the phrase 'the name of the Lord,' which appears in 30:27, occurs throughout the Old Testament linking God's presence to the temple (approx. 30x out of approx. 85x: e.g. $1 \mathrm{Kgs}$ $8: 20$, Solomon 'built the house for the name of the Lord, the God of Israel'). Isaiah in particular employs the phrase seven times outside of 30:27, four of which are related to God's glory or presence in the temple (or 'Mount Zion:' 18:7; 24:15 [cf. 24:23]; 56:6-7; 60:7-9; the

30 Niehaus, God at Sinai: 307-8. 
latter two of which have further unique links with 30:27 because of the common language about the change in the luminescence of the 'sun' and 'moon' in relation to the divine glory: cf. 30:26-27 with $24: 15,23$ and 60:7-9, 19-20).

The reference to God's 'breath' (רציח) in Isaiah 30:28 may merely be an anthropomorphism for God's word in parallelism to the body parts of 'lips' and 'tongue' in verse $27 \mathrm{c}-\mathrm{d}$ or it could be in parallelism with 'the name of Yahweh' in v. 27a. ${ }^{31}$ If the latter, then it may best be rendered 'Spirit.' The LXX of Isaiah 30:27-28 either interprets the MT's apparent reference to God's 'breath' (רוּח) to be God's Spirit or it is in line with an original reference to 'Spirit' in the MT, since it also interprets the MT's reference to 'lips' and 'tongue' in v. 27 repeatedly as God's 'word'32: 'and his Spirit [ $\pi v \varepsilon v \hat{\mu \alpha}]$, as rushing water in a valley, will come [ $\left[\xi_{\varepsilon 1]}\right.$ as far as the neck, and be divided, to confound the nations for vain error ...' That the divine Spirit is in mind here is pointed to further by observing that when $\Pi: 7 / \pi v \varepsilon \hat{\nu} \mu \alpha$ is likened to water elsewhere in the Old Testament, it refers only to God's Spirit performing eschatological work (Isa. 4:4; 44:3; Ezek. 36:25-27; cf. Isa. 32:15; Ezek. 39:29; Joel 2:23 and 2:28; Zech. 12:10; included also here should be Isa. 59:19-21 and, perhaps, Isa. 11:15).

Likewise a 'tongue of fire' (MT; Aq., Sym., and Theod. read $\gamma \lambda \omega \sigma \sigma \alpha \pi v \rho \varsigma)$ occurs as an emblem of judgement in Isaiah 5:24-25 and may be an abbreviated scene of theophanic judgement from the heavenly temple like Isaiah $30,{ }^{33}$ since it also makes allusion to the Sinai theophany (e.g. cf. 'the mountains quaked' in 5:25). ${ }^{34}$

31 See Menzies, “"Tongue(s) of Fire," 34.

32 Though, as noted, Theod. maintains the MT phrase 'the tongue as a consuming fire.'

33 In addition to the common image of a 'tongue of fire,' note also the partly identical language of 'burning anger' (Isa. 5:25 and 30:27).

34 For the allusion to Sinai, see Niehaus, God at Sinai: 308. The heavenly temple scene in Isaiah 6 involves fiery images of God's presence resulting both in blessing (6:6) and in judgment $(6: 13)$. Note also the combined use in Isa. 5:24 and 6:6-7 of 'fire' ( $\pi \hat{v} \rho$, on which see J. Ziegler [ed.], Septuaginta XIV. Isaias [Göttingen: Vandenhoeck \& Ruprecht, 1983]: 143, for Isa. 6) and terms associated with the mouth (respectively 'tongue' and 'mouth'/'lips'). This could point further to Isaiah 5:24-25 being associated with a divine judgment coming from the heavenly temple. Isaiah 6 shows that the same fiery images of judgment can be used positively to indicate preparation for someone to prophesy. Strikingly, Targ. Isa. 6:6 interprets the MT's 'burning coal in his [the angel's] hand' as 'in his mouth there was a speech,' and the burning coal touching Isaiah's mouth in 6:7 of the MT is interpreted as 'the words of my prophecy in your mouth.' 
The 'tongue like a consuming fire' in both Isaiah texts connotes God's judgement ${ }^{35}$ and could be different from the same image in Acts

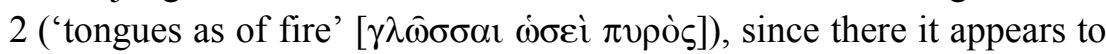
be a sign only of blessing. That the same flaming image even in Acts, however, may also allude both to blessing and judgement is apparent from the Sinai backdrop, where the fiery theophany was associated with both blessing (the giving of the Law) and judgement (for those entering too close to the theophany or rebelling: cf. Exod. 19:12-24; 32:25-29). ${ }^{36}$ We will see below that the background of the Joel 2 quotation in Acts 2 confirms a dual blessing-cursing theme. Consequently, Isaiah's linking of 'tongues of fire,' his 'Spirit' and 'word' to God's descending theophanic presence from a heavenly temple (Isaiah 30), all against a Sinai background, has striking affinities to Acts 2 and points further to the same links in Acts 2.

Among these depictions of God's fire-like voice, Isaiah $66: 15$ is especially apropos and may form part of the background of the Acts 2:2-3 ff. portrayal: 'the Lord will come as fire, and his chariots as a whirlwind to render ... his rebuke with flames of fire.' ${ }^{37}$ The likelihood of its relevance for Acts 2 lies in the following additional observations of its context: (1) as a result of the action in 66:15, God will 'gather all nations and tongues, and they will come and see my glory' (66:18); (2) the description of these nations is expressed through an abbreviated list of the seventy nations from Genesis 10-11, 38 which some have argued is reflected in Acts 2 itself. ${ }^{39}$ (3) It is also noteworthy that God's 'rendering his anger with fury and his [verbal] rebuke with flames of

35 So also Second Targ. (Targ. Sheni) Esther 6:13, where 'a tongue of fire came out of the furnace and consumed' the betrayers of Daniel's three friends, though like the two Isaiah texts, this one in Daniel 3 was likely viewed as judgment arising from a theophany (see Dan. 3:25).

36 In this respect, Philo, Quest. Exod. 2.28 comments explicitly: 'the tongues of fire burn' those coming too close to the Sinai theophany but 'kindle ... with vitality' those who obediently maintain the appropriate distance (following the translation of Marcus, Philo, Supplement II, Questions and Answers on Exodus: 69).

37 See Barrett, Acts: 108, who sees Isa. 66:15-18 possibly in Luke's mind.

38 So See J. M. Scott, 'Luke's Geographical Horizon,' in The Book of Acts in Its Greco-Roman Setting, Edd. by D. W. J. Gill and C. Gempf (Grand Rapids: Eerdmans, 1994): 505-6, 509, 528, 538.

39 See Scott, 'Luke's Geographical Horizon,' 483-544, and idem., Paul and the Nations (WUNT 84; Tübingen: Mohr [Siebeck], 1995): 162-80, and who argues this on the basis of similarities not only to Genesis 10 but also to early Jewish lists that are linked to Genesis 10 (see also his discussion of the history of the various proposed identifications). Scott's argument was anticipated by M. D. Goulder, Type and History in Acts (London: SPCK, 1964): 152-59. 
fire' in 65:15 most likely has its source in the (heavenly?) temple: 'A voice of uproar from the city, a voice from the temple, a voice of the Lord rendering recompense ...' (66:6, which presumably continues the description of God's dwelling from 66:1); in addition, the passage concludes with the nations being made 'priests' and streaming into the eschatological temple ('the house of the Lord') together with returning Israelites (66:20-21, which is a continuation of the same multifaceted theme from 56:3-8), who 'will declare my glory' there (on which cf. Acts 2:11).

There are comparable depictions elsewhere in the OT of God's word being 'fire' (Jer. 5:14; 23:29; cf. Ps. 119:105). Particularly relevant are God's words to Jeremiah (Jer. 5:14: 'I [God] am making my words in your [Jeremiah] mouth fire'). In addition, God's fiery word comes from his heavenly temple: Psalm 18:13 ('And the Most High uttered his voice, / Hailstones and coals of fire' [cf. also Ps. 18:12; 2 Sam. 22:1314], which has its origin from 'out of His temple' [Ps. 18:6]; Ps. 29:7 ('The voice of the Lord hews out flames of fire,' which emanates from the context of 'His temple' [Ps. 29:940]).

\section{Tongues of Fire and Comparable Depictions in Judaism as a Theophany from a Heavenly Sanctuary}

There are some early Jewish writings that could show some awareness of or be inspired by the Old Testament image of 'tongues of fire' being associated with a divine theophany in a heavenly or earthly temple. The phrase 'tongues of fire' also occurs in these Jewish passages. Perhaps a parallel to the fiery 'tongues' of Acts $2: 3$ is

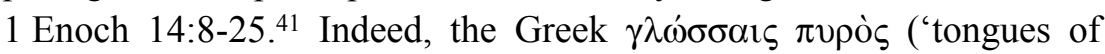
fire') from 1 Enoch 14:9 and 15 (as well as the almost identical 14:10) is virtually the same as $\gamma \lambda \hat{\omega} \sigma \sigma \alpha \mathrm{l} \omega \sigma \varepsilon \dot{i} \pi \nu \rho o ̀ \varsigma$ ('tongues as of fire') in Acts 2:3. There Enoch ascends in a vision to the heavenly temple, apparently the reflection of or model for Israel's earthly tripartite temple. Enoch comes to the wall of the outer court that was

40 C. S. C. Williams, A Commentary on the Acts of the Apostles (Black's NT Commentaries; London: A. and C. Black, 1957): 62, sees this as a probable allusion in Acts 2:2-3.

41 For the Qumran version of this portion of 1 Enoch, see 4Q204 6, 19-29, where also the phrase 'tongues of fire' apparently occurs similarly (though in reconstruction of lacunae; see the Martinez-Tigchelaar DSS Study Edition). 
'surrounded by tongues of fire,' and he 'entered into the tongues of fire' (14:9-10). He then enters through the Holy Place and is able to peer into the Holy of Holies, which was 'built with tongues of fire' (14:15). Likewise in 1 Enoch 71:5 Enoch sees a temple-like 'structure built of crystals; and between those crystals tongues of living fire.'

Thus, the 'tongues of fire' in 1 Enoch 14 and 71 form part of the heavenly temple and contribute to the overall effect of the burning theophany in the Holy of Holies, where 'the flaming fire was around about him, and a great fire stood before him' (14:22). In the 'structure built of crystals' (1 En. 71:5) the saints, together with the 'Son of Man' (71:17), will have 'their dwelling places' (71:16), a plural reference found elsewhere for angels 'dwelling' in smaller 'temples' within the larger heavenly temple (Apoc. of Zephaniah A) and typically used of the OT temple on earth (with its multiple sacred precincts and sections [e.g. with regard to the tabernacle, cf. Lev. 21:23; and with reference to the temple, cf. Ps. 43:3; 46:4; 84:1-4; 132:5, 7; Ezek. 7:24; Jer. 51:51]). Furthermore, when Enoch ascends into the heavenly sanctuary in 1 Enoch 71, he 'cried with a great voice by the Spirit ${ }^{42}$ of the power, blessing, glorifying, and extolling' (1 En. 71:11), which again places the work of the Spirit in the context of the heavenly temple constructed of 'tongues of fire' and is related to eschatological realities (71:15-17).

What could such a heavenly scene have to do with the earthly scene of Pentecost depicted in Acts 2? It is possible that the wording 'tongues of fire' in Enoch is a mere coincidental parallel to Acts 2. On the other hand, the contextual usage of the wording there may have some overlap with the use of the same phrase in Acts 2. The Enoch passage may possibly be a creative development of the above Exodus and Isaiah texts, as well as especially of Ezekiel 1, which themselves are all developments of imagery from the Sinai theophany. For example, the reference in 1 Enoch 14:18 to the 'lofty throne-its appearance ... like crystal and its wheels like the shining sun; and (I heard?) the voice of the cherubim' is clearly a condensed version of Ezekiel 1:21-26. ${ }^{43}$

42 Most translations refer to 'spirit' apparently as Enoch's human spirit, but 'the spirit of power' would be a bit strange in this respect, especially since the divine 'Spirit' has been used for the first time in the Similitudes in 67:10 ('Spirit of the Lord'), followed by $68: 2$ ('the power of the Spirit') and 70:2 ('chariots of the Spirit;' though the uses in 49:3 and 61:11 may refer to the 'Spirit,' since they are allusions to Isa. 11:2), the use in 71:11 being almost identical to the divine reference in 68:2.

43 Other OT passages probably alluded to are Dan. 7:9-10 (= 1 En. 14:19-20) and Isa. 6:1 (=1 En. 14:18a). 
Similarly, commentators have recognized that 1 Enoch 71:1-17 has been woven throughout with OT references from Ezekiel 1 and Daniel 7, as well as the earlier vision of 1 Enoch 14:8-15:2.44

In the light of these Enoch texts, could it be that the descent of the Holy Spirit at Pentecost 'from heaven' in the form of 'tongues of fire' is to be conceived of as the beginning descent of God's temple from heaven in the form of his tabernacling presence? Since the heavenly temple is pictured in the Enoch texts as being partly constructed by 'tongues of fire,' it might be appropriate that the descent of that temple would be pictured with the same thing. Thus, it may be perceivable that, just as the heavenly temple was composed of 'tongues of fire,' within which God's Spirit was active, the new temple on earth (God's people vivified by the Spirit) that had descended from heaven was beginning to be built with the same fiery image. This suggestion may gain more force when seen in the light of the other observations throughout this section, which point from different angles to Pentecost as a phenomenon expressing the divine theophanic presence in the temple, often against the backdrop of the Sinai theophany.

In addition, the Dead Sea Scrolls interpret the Urim and Thummim stones to have shone gloriously with 'tongues of fire' (1Q29). The Urim and Thummim were two stones placed in a pouch in the high priest's breastplate (Exod. 28:30; Lev. 8:8). He was to carry them 'when he enters the holy place ... before the Lord ... continually' (Exod. 28:29-30). Likely these stones were one of the means by which God's prophetic revelation came. They apparently would be cast by the priest or drawn out of the pouch ceremonially, and the way they came out revealed a 'yes' or 'no' answer to the question at hand. ${ }^{45}$ Qumran (1Q29; 4Q376) understands the Urim and Thummim to have shone with 'tongues of fire,' when God gave the prophetic answer in the midst of his theophanic cloud to the high priest's question about whether a prophet is true or false ${ }^{46}$ (in similar vein, Jewish tradition

44 On which see G. K. Beale, The Use of Daniel in Jewish Apocalyptic Literature and in the Revelation of St. John (Lanham: University Press of America, 1984): 109-11, and sources cited therein.

45 See J. A. Motyer, 'Urim and Thummim,' in The New Bible Dictionary, ed. By J. D. Douglas (Grand Rapids: Eerdmans, 1970): 1306, for a concise explanation of the function of the Urim and Thummim in the Old Testament. See 1 Sam. 28:6, e.g. for the prophetic function of the Urim and Thummim: 'When Saul inquired of the Lord, the Lord did not answer him, either by dreams or by Urim or by prophets.'

46 The Qumran text envisions the high priest discovering the prophetic revelation of the Urim and Thummim in the temple (presumably the innermost sanctuary or the 
referred to the Urim and Thummin as 'the Lights' [Pesik. Rab., Piska 8; cf. Targ. Ps-J. Exod. 28:30]).

Therefore, once more we have the 'tongues of fire' as a phenomenon occurring within the 'Holy of Holies' or, more probably, the 'Holy Place' of the temple as an expression of God's revelatory presence (some believe that the square pouch containing the Urim and Thummim symbolized the square shape of the Holy of Holies ${ }^{47}$ ). This time, however, it is the earthly and not the heavenly temple that is the focus, though it should be remembered that the Holy of Holies was viewed as the extension to earth of God's presence in the heavenly temple (recall that the ark of the covenant was referred to as the 'footstool' of the Lord, who was viewed as sitting on his heavenly throne: see 1 Chron. 28:2; Pss. 99:5; 132:7-8; Lam. 2:1; cf. Isa. 66:1). Even more striking is that the 'tongues' in the Qumran text are an occurrence not merely of God's revelatory presence but of his prophetic communication. ${ }^{48}$ This is, of course, what happens at

Holy Place) and then revealing the prophetic answer to the congregation of Israel in the courtyard. Though some deny that the Urim and Thummim are in mind here and argue that the two stones on either shoulder of the high priest are in view (J. Strugnell, 'Moses-Pseudepigrapha at Qumran: 4Q375, 376, and similar Works,' in Archaeology and History in the Dead Sea Scrolls: The New York University Conference in Memory of Yigael Yadin, ed. by L. H. Shiffman [JSPS 8; Sheffield: JSOT, 1990]: 221-56), it is likely the Urim and Thummim are the focus (so M. Wise, M. Abegg, and E. Cook, The Dead Sea Scrolls [San Francisco: Harper Collins, 196]: 178-79, and Menzies, "'Tongues of Fire," 44-55, 59), since the 'Urim' are mentioned twice in 4Q376 (though one occurrence is questionable, since it could be rendered 'they will provide you with light,' though the subject of the verb would likely be the 'Urim' in column 1) and the Urim and Thummim, never any other stones on the priestly clothing, are the only stones that the OT says have a revelatory function (Num. 27:21; 1 Sam. 28:6). The view of Josephus, Ant. 3.214-218, could fit into any of the three above views, though even he is not completely clear (H. St. John Thackeray, ed., Josephus, vol. 4: Jewish Antiquities, Books I-IV [Loeb Classical Library; London: Heinemann, 1930]: 418-19, n. c, even thinks that Josephus's view is erroneous). 1Q29 and 4Q376 are so fragmentary it is difficult to discern clearly whether the stones are those on the priest's shoulders (mentioned in Exod. 28:9) or whether they are the two Urim and Thummim stones (pace Strugnell and Wise, Abegg, and Cook). It may be that, after the priest discovered the revelation of the Urim and Thummim in the temple, he proceeded out with them in the pouch of his breastpiece and the two stones on his shoulders indicated to the congregation outside the revelatory decision, or it could be that the Urim and Thummim were understood to be worn sometimes or always outside on the priest's breast (preferring the latter are Wise, Abegg, and Cook, DSS, 178). The point we are making about the revelatory expression of 'tongues of fire' in the temple setting is not affected by any of the above variations of interpretation.

47 See G. K. Beale, The Temple and the Church's Mission, 39-41.

48 Midr. Rab. Lev. 21.12 likewise affirms that 'when the Holy Spirit rested upon Phineas [the priest], his face flamed like torches about him,' and this is explained by 
Pentecost: not only are the 'tongues as of fire' a manifestation of God's presence in the Spirit, but that presence causes the people to 'prophesy' (as Acts 2:17-18 later makes clear). And the location from which God's Spirit descends at Pentecost would appear to be not only generally 'from heaven' but from the heavenly Holy of Holies or temple, particularly when seen in the light of the descriptions in the Sinai theophany, Isaiah 5 and 30, and the later developments of these images in 1 Enoch 14 and 71, and Qumran.

Thus, all of these passages together collectively contribute from various vantage points to a picture in Acts 2 that resembles something like God's fiery theophanic presence as a new heavenly temple extending from heaven and descending upon his people and making them a part of it. ${ }^{49}$

Mal. 2:7, 'for the lips of a priest should keep knowledge ... for he is the angel of the Lord of hosts.' Thus, strikingly, the priest's exposition of the Law expressed through his 'lips' is compared to a 'flame like torches' and he is identified with a heavenly being. Somewhat similarly, Qumran portrays angelic beings as 'lightning,' 'embers of fire,' and 'flames of fire' in the heavenly temple repeatedly praising God with their 'tongue,' and in so doing they are said to 'make knowledge shine among all the angels [gods] of light' (4Q403, col. II; cf. also 4Q405, Frags. 11, 14-16; Frag. 23 col. 2). Similarly see 2 En. 1:5J ('from their [angels from the heavenly temple] mouths fire was coming forth; their clothing was various singing;' cf. likewise 2 En. 1:5A).

49 I came to this conclusion independently in 2002 in writing the rough draft of my book, Temple and the Church's Mission: 205-8, though Menzies, "Tongues of Fire," (in 2000) is apparently the only other scholar who has also recognized the significance of Isaiah 5, 30, 1 Enoch 14 and 71, and the Qumran 'Three Tongues of Fire' (on which see his citing of the full texts and thorough linguistic analysis), though these texts are

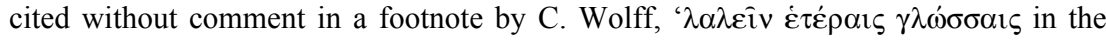
Acts of the Apostles,' in Paul, Luke and the Greco-Roman World, Essays in Honour of A. J. M. Wedderburn, Edd. by A. Christophersen, C. Claussen, J. Frey, and B. Longenecker (JSNTSupp 217; Sheffield: Academic Press, 2002): 189; Fitzmyer, Acts: 238, and Wedderburn, 'Redaction in Acts 2:1-13, 36', merely cite the Qumran evidence and call it respectively 'interesting' and 'suggestive.' R. Longenecker, Acts: 271, mentions 1 Enoch 14 and 71, along with other OT texts, to note that 'fire as symbol of the divine presence was well known among first-century Jews' (E. Haenchen, The Acts of the Apostles [Oxford: Blackwell, 1971]: 168, cites the Enoch texts but sees no significance in them). Among the OT and Jewish texts that Menzies cites, he sees that Enoch and Qumran have the most relevance for Acts 2, and, though in his analysis of each text he acknowledges briefly that they are set in a temple context, he concludes that this Jewish background emphasizes only that 'heaven has come down to earth' and the 'divine accreditation of the glossolalia,' (p. 60), making no comment on the relevance for Acts 2 of the temple setting of these early Jewish passages. 


\section{Prophetic Words of Fire Elsewhere in the New Testament as a Theophany from a Heavenly Sanctuary}

Two texts, both in Revelation, paint a picture similar to Pentecost, although they do not contain the phrase 'tongues of fire.' Revelation 4:5 pictures 'seven lamps of fire burning before the throne,' which is interpreted to be 'the seven spirits of God' (i.e. the Spirit of God). This vision occurs within an overall scene of the heavenly temple where God sits on his throne. ${ }^{50}$ The 'lamps of fire' themselves are conceived of as burning on the temple lampstands, which Revelation has already identified as the churches. ${ }^{51}$ This is probably John's way of portraying the similar reality of Pentecost: the divine Spirit from the heavenly temple has descended and rested on God's people who become part of the heavenly temple on earth, i.e. the lampstands. Revelation 11:3-5 even says that the purpose of the Church becoming lampstands on earth is that they would 'stand before the Lord of the earth' and be 'witnesses' who 'will prophesy' to the 'nations' (cf. 10:11; 11:9) and their prophetic utterance is portrayed as 'fire proceeding out of their mouth'!

This is surprisingly close to Acts 2, where the Spirit from the heavenly temple descends in fire and rests upon God's people in order that they be empowered to 'witness' (Acts $1: 8 ; 2: 40$ ) and 'prophesy' (Acts 2:17-18) to the nations (Acts 1:8; 2:8-11).

Likewise in Judaism God's voice in the heavenly temple or earthly tabernacle or temple is virtually identified with fire. ${ }^{52}$ Later Judaism

50 Note, e.g. the presence of the 'sea' (= the molten sea in the temple courtyard) and the cherubic-like seraphim who guard God's throne in the heavenly temple (by allusion to Ezekiel 1 and 10 and Isaiah 6:1-4).

51 That Revelation 4-5 is a temple scene becomes even more evident as the following visions expand on that initial scene (e.g. 8:3-5; 11:19; 15:5-8).

52 See Midr. Rab. Num. 14.19, which describes God's voice speaking to Moses in the tabernacle as 'a voice' that 'would ... descend from heaven, as though through a kind of tube of fire, to between the two cherubim.' See also Targ. 2 Sam. 22:13 ('his wrath like coals of burning fire from his Memra'); Targ. Isa. 30:27 ('his Memra is like a devouring fire'); 2 En. 39:3 A ('the lips of the Lord are a furnace of fire, and his words are the fiery flames which come out'); 1 En. 61:6 (heavenly beings 'received a command - one voice and one light like fire'); 4 Ezra 13:10 ('he [the man from the sea] sent forth from his mouth as it were a stream of fire, and from his lips a flaming breath, and from his tongue he shot forth a storm of sparks'), which is interpreted in 13:38 to be his judgment of unbelievers by pronouncing the Law, as he stands 'on the top of Mount Zion' (13:35; the 'mountain carved without hands' [13:36] upon which the messianic 'man' flew [13:7] is identified with 'Mount Zion,' and thus closely identified with the end-time temple, to which Dan. 2:34, 45 also refers [on which see Beale, The Temple and Church's Mission, 144-53]. When rabbinic teachers faithfully 
expressed the expectation that the following five things would be restored when the temple and Holy Place were to be rebuilt: 'the ark, the candlestick, the fire, the Holy Spirit, and the cherubim' (Midr. Rab. Num. 15:10). ${ }^{53}$ While this was a hope for a physical end-time temple, the 'fire' and 'Holy Spirit' in Acts 2 would seem to express an inaugurated descent of the eschatological temple in the form of God's presence.

In this connection, the Wisdom of Ben Sirach summarizes Elijah's career in striking likeness to the career of the 'two lampstand-prophets' of Rev. 11:3-4 who sent forth fire and 'shut up the heaven': 'And then stood up Elijah the prophet as fire, and his word burned like a lamp ... he shut up the heaven' $(48: 1,3)$, which is related a few lines later (48:7) to his prophetic experience at Sinai, a background also relevant for Acts 2 (he 'heard the rebuke of the Lord at Sinai, the judgement of vengeance'). Also in close similarity to (and possibly formative for) Acts 2:2, 4 ('like a violent rushing wind ... they were all filled with the Holy Spirit'), Sirach then narrates that Elijah's prophetic mantle is passed on to Elisha: 'Elisha ... was covered with a whirlwind, and Elisha was filled with his [Holy] S[s]pirit' ${ }^{54}$ (48:12).

\section{Pentecost as a Fulfillment of Joel's Prophecy of the Spirit}

Peter explains the theophanic episode of tongues in Acts 2:1-12 to be an initial fulfillment of Joel's prophecy that God would 'pour out' his 'Spirit upon all flesh,' and all classes of people in the covenant community would 'prophesy' (Joel 2:28-29). At the beginning of the

expounded the 'Chariot' and heavenly temple vision of Ezekiel 1-2 (and like OT theophanies), 'fire' would come 'down from the heaven' and cause parts of the creation to 'utter [divine] song' (b. Hagigah 14b; almost identically y. Hagigah 2.1); cf. similarly in association with the same temple visions, Midr. Rab. Lev. 16.4 (a rabbi was 'expounding Scripture, and a flame was burning around him;' so identically Midr. Song of Songs 1.10,2). Cf. Targ. Jer. 23:29.

53 See additional references cited from L. Ginzberg, Legends of the Jews, vol. 6 (Philadelphia: Jewish Publication Society of America, 1928): p. 66, n. 341.

54 Several mss., among which are Alexandrinus, substitute 'Holy' for 'his' or otherwise include it (on which see J. Ziegler [ed.], Septuaginta XII/2. Sapientia Iesu Filii Sirach [Göttingen: Vandenhoeck \& Ruprecht, 1980]: 351). Support for this reading comes also from Sir. 48:24a, where Isaiah the prophet is said to have prophesied by 'a great Spirit' (where also some mss. substitute 'Holy' for 'great,' on which see Ziegler, Sirach, 354). 
Joel 2:28 quotation, Peter substitutes the phrase 'in the latter days' ('ं v

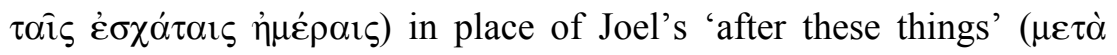
$\tau \alpha \hat{v} \tau \alpha$ ). The substitution comes from Isaiah 2:2 (the only place in the LXX where this precise phrase occurs) ${ }^{55}$ : 'In the last days, / The mountain of the house of the Lord / Will be established as the chief of the mountains / And will be raised above the hills; / And all the nations will stream to it.' Thus, Peter appears to interpret the Spirit's coming in fulfillment of Joel to be also the beginning fulfillment of Isaiah's prophecy of the end-time temple, under the influence of which the nations would come.

In the Mosaic era, only prophets, priests, and kings were bestowed with the gifting function of the Spirit to serve, often in the temple (e.g. priests) or sometimes in conjunction with the temple (i.e. kings and prophets). Joel and Acts do not have in mind primarily the regenerating function of the Spirit but that function which would enable people to serve in various capacities. Joel foresaw a time, however, when everyone in Israel would be given this gift. That Joel 2 and Acts 2 may have in mind gifting for service in connection in some way with the new temple is apparent from recognizing that Joel's prophecy is developing the earlier text of Numbers 11.56

Moses desires that God give him help to 'bear the burden of the people' he was leading (Num. 11:11, 17; Exod. 18:13-27). God responds by telling Moses to gather 'seventy men from the elders' and to 'bring them to the tent of meeting, and let them take their stand there with you. Then I will come down and ... will take of the Spirit who is upon you, and will put Him upon them' (11:16-17). Moses obeys God: 'he gathered seventy men of the elders ... and stationed them around the tent. Then the Lord came down in the cloud ... and He took of the Spirit who was upon him and placed Him upon the seventy elders. And it came about when the Spirit rested upon them, they prophesied ...' (11:24-25). They then stopped prophesying, but two elders at another location continued to prophesy. When Joshua hears about this, he asks Moses to stop them. Moses declines to do so, replying: 'Would that all

55 On which see D. Pao, Acts and the Isaianic New Exodus (WUNT 2;130; Tübingen: Mohr Siebeck, 2000): 156-59.

56 R. B. Dillard, 'Intrabiblical Exegesis and the Effusion of the Spirit in Joel,' Creator Redeemer Consummator, Festshrift for M. G. Kline, edd. by H. Griffith and J. R. Muether (Greenville, South Carolina: Reformed Academic Press, 2000): 87-93, who demonstrates that Joel develops Numbers 11:1-12:8. 
the Lord's people were prophets, that the Lord would put His Spirit upon them' (see 11:26-29).

Accordingly, Joel 2 transforms Moses' prophetic wish into a formal prophecy. Peter quotes Joel's prophecy to show that in his day it was finally beginning fulfillment in Pentecost. The Spirit's gifting, formerly limited to leaders helping Moses and imparted to them at the tabernacle, is universalized to all of God's people from every race, young and old, male and female. That the Spirit's gifting in Acts 2 was connected in some way to the temple is apparent from Numbers 11, which notes twice that the 'seventy elders' received the Spirit as they were gathered around the 'tent' (i.e. the tabernacle). In fact, that in Acts 'tongues of fire ... rested [lit., "sat"] on each one' and 'they were all filled with the Holy Spirit and began to speak with other tongues' (2:34, explained to be 'prophesying' in 2:17-18) appears to be an allusion to Numbers 11:25: 'when the Spirit rested upon them, they prophesied.' 57

Interestingly, later Judaism compares the Numbers 11 text about the Spirit from Moses resting on the elders 'to a candle that was burning and at which many candles were kindled ...' (Midr. Rab. Num. 15:19; so also Midr. Rab. Num. 13:20; so likewise Philo, On the Giants 24 25, who says the Spirit from Moses in the same Numbers passage was comparable to a 'fire' that 'kindle[s] a thousand torches'). Furthermore, Numbers 11:25 says that God 'took of the Spirit who was upon him [Moses] and placed him upon the seventy elders.' Likewise, Acts 2:33 refers to Jesus as first 'having received from the Father the promise of

57 See similarly Num. 11:29, which the $\mathrm{NA}^{27}$ cites as an allusion for Acts 2:18b ('I will in those days pour forth of my Spirit and they shall prophesy'). Together with Num. 11:25, Acts 2:3b-4a also may allude to Num. 11:26 where the 'Spirit rested upon' some of the elders 'and they prophesied' (cf. also Num. 11:17, 29; similarly, $\mathrm{NA}^{27}$ proposes that Acts 2:3 alludes to Num. 11:25). There is some evidence in the textual tradition of Num. 11:26, 29 for the reading of 'Holy Spirit' in line with the same phrase in Acts 2:4 (see J. W. Wevers, Septuaginta XIV. Numeri [Göttingen: Vandenhoeck \& Ruprecht, 1982]: 167-68). Likewise, Targ. Neofiti 1 Num. 11:17, 25 26, 29 reads 'Holy Spirit.' The occurrence of the 'Spirit' coming and causing 'prophesying' appears also in $1 \mathrm{Sam} .10: 6,10,1 \mathrm{Sam} .19: 20,23$, Luke 1:67, and 2 Peter 1:21. The preceding verses refer respectively to the gifting of a king of Israel and his official servants, to a priest in the temple, and to Old Testament prophets, thus showing the association of the Spirit's gifts in the OT only with these three classes of people. 
the Holy Spirit' and then having 'poured forth' the Spirit upon those at Pentecost. ${ }^{58}$ In this respect, Jesus may be a second Moses figure.

Even the prophesying of the 'seventy' in Numbers 11 may have links with the people prophesying in Acts 2 . We have seen that some commentators believe the list of nations represented at Pentecost (Acts 2:9-11) is an abbreviated allusion to the seventy nations of the earth in Genesis 10, and it may even be apparent that the Acts narrative is a further development of Luke's earlier narration of Jesus' sending of the 'seventy' select Israelites to symbolize a beginning witness to the 'seventy' nations of the world (Luke 10:1-12).59 Thus the links between the seventy nations represented in Acts 2 and the 'seventy' of Numbers 11 may not be coincidental. Judaism also combined the Numbers 11 text with Joel 3:1 to speak about the blessings 'in the world-to-come' (Midr. Pss. 14:6; Midr. Rab. Num. 15:25).

Likewise, Numbers 11:24-29 is itself an allusive development of both unique themes and phrases in the Exodus 24 Sinai episode: in both contexts (1) Moses appoints seventy elders (2) as 'the spirited leaders' of the people (e.g. cf. use of איצ in Exod. 24:11 and Num. 11:16-17) (3) in order to help govern the nation; (4) part of the validation of their office comes through vision of God's descent in a 'cloud' and his revelation, which they experience together with Moses at a sacred site or sanctuary; (5) both passages are preceded by and sparked by Israel's sin in connection with complaints about food (Exod. 16:2; Num. 11:1), the daily bestowal of manna (Exod. 16:16b21; Num. 11:6-9), and the mention of the coming of quail (Exod. 16:13a; Num. 11:13, 18-23, 31-34). ${ }^{60}$ We should not be surprised to learn of this allusive connection between Exodus 24 and Numbers 11, since we have seen above that the Sinai theophany is also developed in Joel 2 and in Acts 2. We appear to be dealing with organic threads connecting, in one way or another, all of these passages, and whether they came to Luke's interpretative pen already connected in some prior

58 See I. H. Marshall, 'The Use of the Old Testament in Acts,' in Commentary on the Use of the Old Testament in the New Testament, edd. by G. K. Beale and D. A. Carson (Grand Rapids: Baker, forthcoming), in loc., who argues that Num. 11:25, 29 was a 'model' for Luke's description of 'the descent of the Spirit on the people and their consequent speech.'

59 Following Scott, Paul and the Nations: 162-63.

60 See J. R. Levison, 'Prophecy in Ancient Israel: the Case of the Ecstatic Leaders,' $C B Q 65$ (2003): 514-16, for expansion of these parallels, including parallel phraseology. 
exegetical tradition or whether Luke made the connections is not clear (though in the former case it is likely that Luke still would have been aware of much of the OT background).

\section{Pentecost as a Fulfillment of Joel's Prophecy of the Destruction of the Old World and Emergence of a New Order and Temple}

One further observation about the concluding part of Joel's prophecy is that it is stock-in-trade Old Testament cosmic dissolution language. The portrayal in Joel is part of a group of similar texts: Isaiah 13:10-13; 24:1-6, 19-23; 34:4; Ezekiel 32:6-8; Joel 2:10; 2:30-31; 3:15-16; and Habakkuk 3:6-11 (possibly also Amos 8:8-9, Jer. 4:23-28, and Ps. 68:7-8). The majority of these texts are themselves portrayed in terms of the prototypical Sinai theophany and are evocative recollections of that first great appearance of God to Israel. ${ }^{61}$ In fact, Joel 2:30-31 (together with 4:15 [3:15]) itself is one of the clearest 'eschatological theophanies of the Sinai type. ${ }^{62}$ This observation enforces our earlier contention that the Sinai theophany is a significant background against which to understand Acts 2. Furthermore, the link between Joel 2 and the Sinai phenomenon may suggest that the revelation of God's fiery law in the latter is interpreted eschatologically by the former as the 'pouring out of the Spirit.'

The language of these Old Testament passages describes the destruction of the cosmos. Typically, the language is figurative to refer to the historical end of a sinful nation's existence through divine judgement and the emerging dominance of a victorious kingdom. God executes the judgement by employing one nation to defeat another in war. Though the tone of judgement is dominant, sometimes there is a positive aspect resulting in the deliverance or refinement of a faithful remnant (especially when Israel is the object of the judgement). Such figurative language occurred because prophets had a literal conception of the end of history, and they applied this metaphorically to the ends of various epochs or kingdoms during the Old Testament era. ${ }^{63}$

61 Niehaus, God at Sinai: 280-332.

62 Niehaus, God at Sinai: 328-29.

63 E.g. note the defeat of Babylon (Isa. 13:10-13), Edom (Isa. 34:4), Egypt (Ezek. 32:6-8), enemy nations of Israel (Hab. 3:6-11), of Israel herself (Joel 2:10 and Joel 2:30-31; cf. Sib. Or. 3:75-90. Other examples in the OT of figurative cosmic disruption 
The same expression found in Joel 2:10 occurs again in Joel 3:15a ('The sun and moon grow dark') that likewise probably refers to the same reality as in Joel 2:31 ('the sun will be turned into darkness and the moon into blood'). In 3:16-18 the appearance of the Lord comes from 'Zion' and is in the 'holy mountain,' and is inextricably linked to 'the house of the Lord.' ${ }^{64}$ Joel 3 clarifies what Joel 2 may already have implied twice about the origin of revelatory cosmic destruction, since in 3:17 it also occurs in connection with 'Zion my holy mountain' (cf. $2: 1$ ['Zion ... my holy mountain'] and 2:2-11; likewise 2:31 and 2:32 ['Mount Zion']). The emphasis on God's 'tabernacling' presence in the temple at the end of Joel 3 is also expressed through the twice-repeated

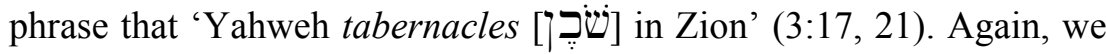
have one more indication that theophanic revelation connected with Joel 2:30-31 comes from or appears in the end-time temple, suggesting further that the theophany in Acts 2 also comes from the heavenly sanctuary. A study by C. A. Evans suggests that the sanctuary from the last chapter of Joel could be within the peripheral vision of Luke (or Peter). ${ }^{65} \mathrm{He}$ has argued that the entire context of the book of Joel (including the last chapter) appears to be in Luke's peripheral vision: in addition to the quotation of Joel 2 in Acts 2:17-21, there are other allusions and echoes from throughout Joel that can be detected throughout Acts 2:1-40 (though Evans does not mention the sanctuary reference from Joel).

Joel 2:30-32 also indicates that not only judgement but blessing results from the theophanic revelation. As is typically true in the other Old Testament texts using the same imagery, Joel's cosmic destruction language means that judgement comes, but also that a faithful remnant survives the judgement. Joel 2:32 says that 'whoever calls on the name of the Lord will be delivered ... There will be those who escape ... even among the survivors whom the Lord calls.' And, as we have seen,

language is: above all, 2 Sam. 22:8-16 (= Ps. 18:7-15, figuratively referring to David's victory over his enemies); Eccles. 12: 1-2ff., referring to human death; Isa. 2:19-21; 5:25, 30; Ezek. 30:3-4, 18; Amos 8:7-10; Jer. 4:23-28; Micah 1:4-6. There are also passages where the same language could possibly be understood literally: Isa. 24:1-6, 19-23; 51:6; 64:1; Ps. 102:25-26; Ezek. 38:19-20; Hag. 2:6-7; in addition, this language describes the past theophanic events at Mount Sinai (Exod. 19:18; Deut. 4:11; Ps. 68:7-8; Ps. 77:18). Interestingly, Midr. Pss. 104.25 says, 'Wherever the term 'earthquake' occurs in Scripture it denotes the chaos between [the fall of] one kingdom and [the rise of] another.'

64 The Targum here (= Joel 4:16-18) reads 'sanctuary of the Lord.'

65 Evans, 'The Prophetic Setting of the Pentecost Sermon,' ZNW 74 (1983): 148-50. 
some in Acts 2 respond in faith in Christ and are 'saved.' This faithful remnant is the beginning of the new people of God, the continuation of true Israel, and, what we have argued, the initial corporate form of the new spiritual temple. On the other hand, the phenomenon of 'tongues,' though a sign of blessing (as we have seen), is also a harbinger of judgement, as is the cosmic conflagration language of Joel.

\section{Conclusion}

We have argued from various perspectives that Acts 2 depicts not merely a theophany but also the descent of the heavenly end-time temple of God's presence upon his earthly people. They are constructed to be part of God's temple, not with physical building materials, but by being included in the descending presence of his Spirit. Our argument is a cumulative one, so that, while some parts of the evidence may not be as strong as others, the intent is that the overall weight of the proposal be effective. All of the Old Testament allusions and related Jewish parallels are integrally connected to a picture of a temple, often a heavenly or eschatological one. Some of these allusions may overlap with one another to form one mosaic image or picture, especially with respect to, for example, the Sinai theophany (e.g. the various OT and Jewish theophany texts portraying God's voice or tongue as fire, much like John's synthesis of theophany texts of the Exodus Sinai, 1 Kings 22, Isaiah 6, Ezekiel 1 and Daniel 7, which have provided the Vorbild for Revelation 4-566).

Part 2 of this article will investigate all of the other usually recognized Old Testament quotations and allusions throughout Acts 2:1-40 in order to assess how they may or may not relate to the temple theme that we have so far traced in the above essay. A final, overall conclusion will be formulated at the end of the second article.

66 On which see G. K. Beale, 'The Use of the Old Testament in Revelation,' in It Is Written: Scripture Citing Scripture, ed. D. A. Carson and H. G. M. Williamson and (Cambridge: University Press 1988): 325. 


\section{Excursus: Sinai as a Temple}

First, Sinai is called 'the mountain of God' (Exod. 3:1; 18:5; 24:13), a name associated with Israel's temple on Mount Zion. ${ }^{67}$

Second, just as with the tabernacle and temple, so Mount Sinai was divided into three sections of increasing sanctity: the majority of the Israelites were to remain at the foot of Sinai (Exod. 19:12, 23), the priests and seventy elders (the latter functioning probably as priests) were allowed to come some distance up the mountain (Exod. 19:22; 24:1), but only Moses could ascend to the top and directly experience the presence of God (Exod. 24:2). In this respect, God told Moses to 'set bounds about the mountain and consecrate it' (Exod. 19:23), since if anyone except the seventy elders, Aaron, and Moses 'touched' the mountain, they would 'be put to death' (Exod. 19:12). This is language uniquely reserved elsewhere for the tabernacle:68 'And when Aaron and his sons have finished covering the holy objects and all the furnishings of the sanctuary, when the camp is to set out, after that the sons of Kohath shall come to carry them, so that they may not touch the holy objects and die. These are the things in the tent of meeting which the sons of Kohath are to carry' (Num. 4:15; see likewise Lev. 7:20-21; 22:1-9; for a positive version of Num. 4:15, see Exod. 30:29: 'you shall consecrate them [the tabernacle and its contents]; whatever touches them shall be holy'69). So holy was the entire apparatus of the tabernacle that even if 'regular priests' directly handled any part of it, they would die.

Third, just as an altar was in the outermost section of the temple, so an altar was built at the lowest and least sacred part of Sinai. Furthermore, at this altar Israel 'offered burnt offerings and sacrificed young bulls as peace offerings to the Lord. And Moses took half the blood and ... sprinkled [it] on the altar' (Exod. 24:5-6), sacrificial language often found elsewhere almost always in connection with the tabernacle or temple. ${ }^{70}$

67 See 'mountain of the Lord' as a virtual synonym for 'house of God' in Isaiah 2:2-3 and Micah 4:2; for almost identical names, see below.

68 A thought inspired by Otto Betz, 'The Eschatological Interpretation of the SinaiTradition in Qumran and in the New Testament,' Revue de Qumran 6 (1967): 94-95, 106.

69 For the 'consecration of these cultic objects, see also Exod. 29:36 -37, 44; 40:9-10; Lev. 8:11;16:19.

70 R. E. Averbeck, 'מִזכברח', NIDOTTE, vol. 2: 890-96, argues that the apparent tension between Exod. 20:24-26 (which he sees being a law about multiple altars not in 
Fourth, not only does the top part of Sinai approximate the Holy of Holies because only Israel's 'high priest,' Moses, could enter there, but it was the place where God's theophanic 'cloud' and presence 'dwelt' (Exod. 24:15-17; for Moses as a 'high priest' see Philo, Vit. Mos. 2:75). Significantly, the only other times in all of the Old Testament that God's presence is spoken of as a 'cloud dwelling' is with respect to God's presence above the tabernacle (Exod. 40:35; Num. 9:17-18, 22;

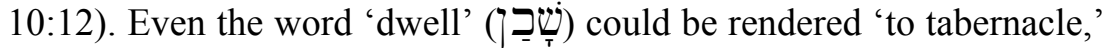

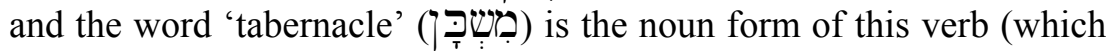
is used with the verb in three of the four preceding texts). So also 1 Kings 8:12-13 says that God 'would dwell in the thick cloud' in the temple completed by Solomon. Furthermore, the 'ten commandments' and the 'ark' are created at the top of Sinai (Deut. 10:1-5), just as later they find their place in the inner sanctum of the temple, once again in God's presence.

Fifth, earlier in Exodus God's presence at Sinai was depicted as a "cassia tree [סֶ, or "bush"] burning with fire, yet the cassia tree was not consumed' (Exod. 3:2). In the light of the parallels already

the temple) and Deuteronomy 12 (which allows for only one altar in one temple) is to be resolved by understanding that the latter law would not go into effect until the Solomonic temple was built, but that up until that time multiple solitary altars were legitimized. If so, our point about the altar might be diluted, since altars would be present where the tabernacle or temple is not. The limits of this excursus do not allow for much evaluation of Averbeck's thesis. Nevertheless, after all the evidence is assessed, any of the 'conservative' views that he reviews but rejects are at least as plausible, if not more, than his, especially the perspective that until the Solomonic temple was built, solitary altars were acceptable on special occasions but not on a regular basis; and even before Solomon's temple, a central sanctuary was present wherever the tabernacle was located, since the latter was the official temporary precursor of the former. The point here about Exod. 24:5-6 is based particularly on the fact that wherever the phrase 'burnt offerings' and 'peace offerings' (approx. 50x, almost always in this order) occur (outside Exodus 20 and 24), sometimes in combination with 'altar' (or otherwise the 'altar' is implied), either the tabernacle or the temple is the typical location (the only clear exception is $1 \mathrm{Sam}$. 10:8 and 13:9, but even here, the high priest should have been the officient performing the sacrifices, and this exception may prove the rule; the apparent exceptions are: Exod. 32:6 [though, again, at the foot of Sinai]; Deut. 27:6-7 + Josh. 8:31; 22:23, 27 [the point of these last two verses is that such offerings are to be directed to the legitimate site of sacrifice in the land]; Judges 20:26;21:4 [but in each of these two passages, as well as in Deut. 27 and Josh. 8 above, context shows that the tabernacle is in the background as the location]). Thus, it is best to take Exod. 20:24-26 to be addressing the same issue as Deuteronomy 12. Interestingly, Averbeck's own proposal ultimately comes substantially close to the last version of the conservative views noted above. Averbeck does see that the 'burnt offerings' and 'peace offerings' 'sacrificed' at the Sinai 'altar' in Exod. 24:4-8 were formative for blood offerings at the tabernacle which are narrated elsewhere in the Pentateuch ('Offerings and Sacrifices', NIDOTTE, vol. 4: 1001-3). 
adduced, this 'unconsumed burning tree' may be the proleptic equivalent to the lampstand-like tree in the Holy Place on Mount Zion, whose lamps burned continually. ${ }^{71}$ Correspondingly, the ground around the burning tree is called 'the place' of 'holy ground' (Exod. 3:5). The correspondence of this small area at Sinai with the later 'Holy Place' is seen from the only other uses of 'holy place' in Hebrew, four of which refer to the section of the sanctuary directly outside the 'Holy of Holies' (Lev. 7:6; 10:17; 14:13; 24:9) and the remaining two refer to the temple in general (Ezra 9:8; Psa. 24:3).

In the light of the association of Sinai as a temple, it may not be accidental that Revelation 11:19 later alludes to the theophanic phenomena at Sinai in describing the opening of the heavenly Holy of Holies at the end of history, when 'the ark of his covenant' will be revealed ('there came about lightnings and sounds and thunders'). ${ }^{72}$ Indeed, it has been observed by others that the building of the tabernacle itself appears to have been modelled on the tripartite pattern of Sinai. ${ }^{73}$

71 G. P. Hugenberger mentioned this idea to me in a private communication in Spring, 1999. I have also found this view proposed by T. Longman, Immnauel in Our Place (Phillipsburg: Presbyterian and Reformed, 2001): 57.

72 For the allusion to Sinai in Revelation 11:19, see R. Bauckham, The Climax of Prophecy (Edinburgh: T. \& T. Clark, 1993): 202-4. Similarly, Jewish tradition believed that at the final resurrection, 'the ark will be the first to be resurrected ... and be placed on Mount Sinai' (Lives of the Prophets 2:15), implying the belief that Sinai itself was a mountain temple. See also Midr. Rab. Num. 15.19 (cited earlier).

73 After writing the rough draft of this section, I have found that the following scholars are a sampling of those who have argued this on the basis of many of the same observations made above: N. M. Sarna, Exodus (JPS Torah Commentary: Philadelphia: Jewish Publication Society, 1991): 105; Mary Douglas, Leviticus as Literature (Oxford: University Press, 1999): esp. 59-64; P. Enns, Exodus (NIV Application Commentary; Grand Rapids, 2000): 391, who follows Sarna. 